\title{
THE GROWTH IMPERATIVE (TGI): AN APPROACH TO
} ALLEVIATE/ERADICATE POVERTY

\author{
Leandro Adolfo Viltard \\ Pontificia Universidad Católica Argentina \\ Graduate School of Business, Facultad de Ciencias Económicas, \\ Universidad de Palermo, Argentina \\ Universidad de San Isidro (USI), Argentina \\ Universidad del Pacífico, Ecuador \\ Universidad Nacional de La Pampa, Argentina \\ Universidad Nacional de Luján, Argentina \\ Universidad Nacional del Comahue, Argentina \\ E-mail: Iviltard@yahoo.com.ar
}

Submission: 04/04/2018

Revision: 25/04/2018 Accept: 11/05/2018

\section{ABSTRACT}

Poverty has become one of the central issues of our society. For governments and organizations it is much more than a strategic, marketing or philanthropic issue; it is one of the scourges that whip our society. A new logic must emerge in order to lay the foundations for the upcoming world. This should contain a deeper understanding of emerging economies customers' needs and on consumption differences between the developed and the developing worlds. The hypothesis of this work -which is corroborated as the main conclusion of the study- suggests that the three theories that are presented -if combined and with a deeper comprehension- may help to alleviate/eradicate poverty, through giving dignity and better choices to the people who live at the Bottom of the Pyramid (BoP) and changing the actual dominant logic that inhibits worldwide development. This objective may be achieved through The Growth Imperative Pillars, presented in this work. The study is exploratorydescriptive, with a qualitative methodology. It is based on a bibliographical review of renowned specialists on the subject. 
INDEPENDENT JOURNAL OF MANAGEMENT \& PRODUCTION (IJM\&P)

http://www.ijmp.jor.br

v. 9, n. 4, October - December 2018

ISSN: 2236-269X

DOI: 10.14807/ijmp.v9i4.816

Keywords: Bottom of the Pyramid (BoP); Reverse Innovation (RI); Disruptive Innovation (DI); Innovation; Creativity; Competitive advantage; Corporate culture; Leadership

\section{INTRODUCTION}

Poverty has become one of the central issues in our society. Prahalad (2004) says that most governments of the world had struggled for decades on this subject showing alarming results: almost 5 billion people (+71\% of total population) belong to the BoP where there have not been seen solutions that would help its eradication/alleviation. Moreover, states that generally the emerging markets' population lives -in different geographies- at the BoP, which is a latent market.

These are forgotten realities for many governments and organizations but -if the actual dominant logic is changed- they could be part of a fresh business ecosystem in which a novel set of innovations may occur.

In this environment, the scope of this study is about three strong theories that are shown as complementary and may help with this scourge: 1) the Bottom of the Pyramid (BoP), 2) Reverse Innovation (RI) and 3) Disruptive Innovation (DI).

This work finds its main motivations in the enormous challenges and opportunities that poverty puts in our society, taking into account the following factors:

- It is one of the big unresolved problems, making difficult the worldwide development if demand is not expanded.

- The past methods showed imperfection and bring us to observe an unobjectionable and worsen reality, with no visible results, and an alarming situation for many people of the world.

- Through Corporate Social Responsibility (CSR)/Shared Value Chain (SVC) principles, executives of private firms and social organizations, and -alsogovernment officials are increasingly becoming conscious on poverty's perils and opportunities, being more able to intervene in this reality.

- There are more and better tools available in order to manage people's creativity, as well as there is an increasing executives' interest in exploiting it. 
INDEPENDENT JOURNAL OF MANAGEMENT \& PRODUCTION (IJM\&P)

http://www.ijmp.jor.br

v. 9 , n. 4, October - December 2018

ISSN: 2236-269X

DOI: 10.14807/ijmp.v9i4.816

This challenge needs huge creativity reservoirs to give better replies on this fact.

As a consequence, the present research identifies what is called "The Growth Imperative Pillars" -that favors organizational development through strong theoriesfrom which future competitive advantages may come out in order to alleviate leradicate poverty, and give dignity and better choices to the people of the BoP.

The following questions have allowed deepening in the subject of this study:

- Is poverty a scourge of emerging economies only?

- Are there strong and innovative theories that may help to alleviate/eradicate poverty?

- Is globalization the only possible avenue to export products worldwide and help growth?

- Is profitability possible producing and selling simpler products at lower cost/price point?

The final objective of this work is to deepen in the understanding of the BoP and applicable novel innovation theories in order to alleviate/eradicate poverty and give dignity and better choices to the poor all over the world.

The hypothesis of this work suggests that the three theories that are presented -if combined and with a deeper comprehension- may help to alleviate/eradicate poverty, through giving dignity and better choices to the people who live at the Bottom of the Pyramid (BoP) and changing the actual dominant logic that inhibits worldwide development. This objective may be achieved through The Growth Imperative Pillars, presented in this work.

After finishing this investigation, it is possible to say that its objective was verified and the hypothesis was corroborated.

The study is exploratory-descriptive, with qualitative methodology. In addition, it is holistic because it includes a wide configuration in which the studied object is located.

As a bibliographical investigation, data collection involved the study and analysis of information obtained through relevant international secondary sources. 
INDEPENDENT JOURNAL OF MANAGEMENT \& PRODUCTION (IJM\&P)

http://www.ijmp.jor.br

v. 9, n. 4, October - December 2018

ISSN: 2236-269X

DOI: 10.14807/ijmp.v9i4.816

This research ranged from June, 2017 to April, 2018, and was performed in Buenos Aires, Argentina.

\section{THE BOTTOM OF THE PYRAMID (BOP)}

Prahalad (2004) states that poverty can be alleviated/eradicated through giving poor people options and dignity, and including them in the economic value chain. Also and from a worldwide population of approximately 7 billion people, the poor is a vast reality of approximately 5 billion people, living in difficult-to-live areas of different countries. Moreover, he admits that most of the marketing ecosystems are directed to the 2 billion people top market.

But BoP markets are not limited to emergent economies only. The Economist (2011) states that, in the world's richest countries, the hard-up represent an immense and growing market. In the period 2005-2009, the average American saw a decline in his income and millions of middle-class people were forced to downshift due to expenses increase (like colleges and health care) and credit dry up.

Additionally, approximately 44 million Americans are living below the official poverty line and consumer spending per household fell by $2.8 \%$ in 2009 (the first time it had fallen since 1984). Also, that broadband penetration is stabilized at nearly two-thirds of households and pay-TV is declining its penetration.

The article suggests that:

- This is an opportunity for American firms like McDonald's that from 2006 had grown 4\% its annual sales, despite the increase in food prices. Also, it can be for companies of the emerging markets like TracFone Wireless -Méxicothat, since 2008, sold +3 million pre-paid cellular phones in USA; or MedicallHome -México- that provides phone health care advise for $\$ 5$ a month as well as access to their 6,000 doctors network; or Tata -from Indiaand Haier -from China- that are looking at USA as a possible market for their frugal products.

- Frugal shops are rising in USA, too. Target and Wal-Mart are entering in new markets (such as basic medical care) and new places (like inner cities), and Aldi -a German discounter- is doing well in USA. They use unfancy brands, less products in stock and they improve the places to shop (like Aldi). Also, 
Wal-Mart expanded its groceries section, McDonald's sells healthy fast food, and Dunkin' Donuts and McDonald's are challenging Starbucks by offering a drinkable coffee at cheaper prices.

- Firms like Pawngo are giving loans to "college-educated working professionals with temporary cash flow problems", Leap Wireless and MetroPCS has shown an impressive growth as pre-paid wireless providers and Houston's Direct Energy with a pre-paid plan for electricity.

- There is space for collaborative consumption, allowing people to share or rent rather than own. ThredUp enables to swap children's cloths and CouchSurfing offers its users hospitality exchange and social network services.

The conclusion is that firms' complacency open up a place for agile and optimist competitors, and that the BoP is a vast territory where companies that may offer ultra-low prices will have plenty of possibilities everywhere.

Prahalad (2004) -in order to help the development of the BoP market, where it is verified that there is money and access to products- proposes a convergence between BoP solutions and clean technologies, taking into consideration two fundamental assumptions:

1) They are not State orphans and they must be turned into valid consumers. That's the reason why this population should be seen as a possible market and as a source of innovation.

2) They are neither victims nor a burden; not needing subsidies. They should be considered a basic element of private firms' central mission, and recognized as consumers with a sense of value and creative entrepreneurs.

As a consequence, the author:

- Understands that the economic development and social transformation must come from private organizations, local governments, civil society organizations, BoP consumers and entrepreneurs, and agencies of development and assistance. 
- Cites firms that are struggling and making profits in this vast worldwide market (like Cell Tell, Safari.com, Airtell, Reliance and Globe), and other organizations that are helping people to:

o Have clean energy (Tecnosol, Nicaragua).

o Decent housing and neighborhoods (Cemex, México).

o Walk regardless of whether they are disabled (Jaipur Foot).

o Fight diseases with educational campaigns and innovative products (Voxiva, Perú).

o Home appliances and furniture (Casas Bahía, Brazil).

o Monitor the prices of farmers' crops and be in connection with the world through computing (ITC-eChoupal, India).

Through these alternatives, poor people can have both additional profits and/or savings, as follows:

a. Additional profits, like through ITC-eChoupal, which gives the opportunity to sell crops when the farmer decides to and at market prices, not through a government authority/office.

b. Extra savings, like Cemex, that teaches to save and invest in their homes to poor people or Casas Bahía that helps them to have basic things for their lives, having developed a sophisticated credit rating system and a specific psychological counseling.

Prahalad (2004) adverts that the initial step of the whole process is to be respectful of BoP consumers -who must be committed and activist-, and to offer them options and feed their self-esteem. The challenge is to find creative and new ways to transform poverty into an opportunity for everybody, through defying our actual dominant logic, as follows:

- Inventing ways that take into account the amount and variability of consumers' cash flows in this market. They earn not much, probably between 2 and 9 US 
dollars a day ${ }^{1}$, and if they lose one job their earning won't vary a lot as they have others.

- Considering that with the actual cost structure it is impossible to serve this market. Voxiva is an example: in Perú, they fight against diseases with creative solutions. For instance, they survey people affected to certain diseases with local people, not with doctors, using a series of photographs that show the state and evolution of the disease. This is a cheaper method to survey when compared to utilizing doctors.

- Being more committed to product's functionality, not to its form. In this sense, poor people need hygiene or groceries products but in the larger formats bought by people with greater purchasing power the BoP consumer purchase is impossible.

- Focusing on new and advanced technologies, if needed. For example, in these markets ATM with fingerprinting reading are used as poor people cannot read, but also, a Tata Nano -a simple and cheap car of approximately $\$ 2,800$ dollars in India- is needed too.

- Considering that the best top executives should be assigned to BoP projects, helping in their development.

The study concludes that:

- The BoP is not a company distraction, being a latent market of products and services.

- It is required an inclusive capitalism, as BoP is a huge growth and innovation opportunity for everybody.

- We should forget the old and worn solutions if we want to develop this market.

In the following Figure 1, it is shown a summary of this section:

${ }^{1}$ This sum of money depends on the publication that is considered. The fact is that BoP individuals earn not much money per day. 


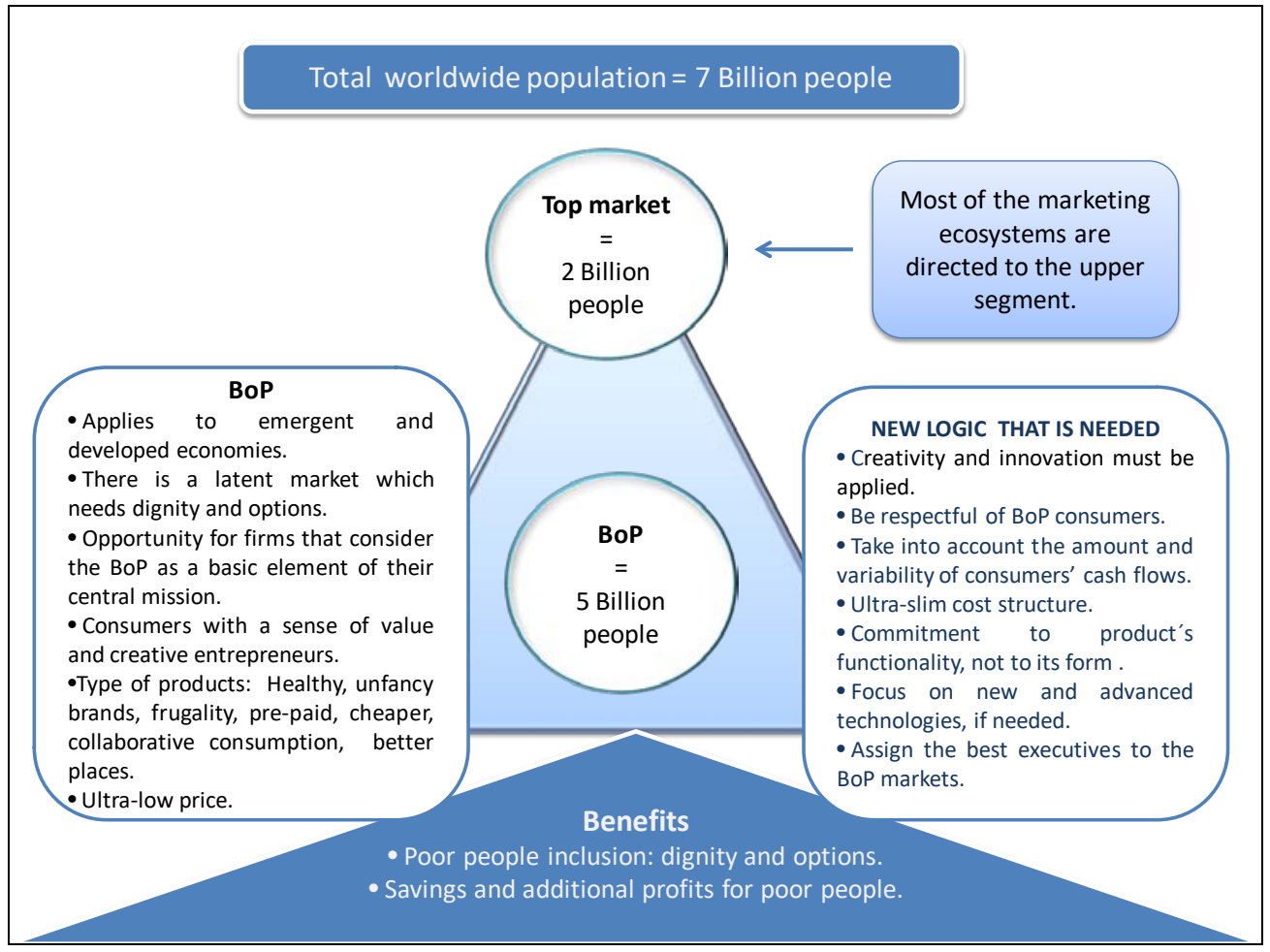

Figure 1: The Bottom of the Pyramid (BoP)

Source: Own

\section{REVERSE INNOVATION (RI)}

Govindarajan and Trimble (2012) suggest that exporting is not the only way to unlock opportunities for multinationals, and that understanding RI is a new path for growth and development.

They remark that we all expect that the future will be discovered in the West (Silicon Valley or Munich, for example) but not in the East (Bangladesh), and that developing countries don't need innovations because they will import them from the rich world. This idea relies on the affordability concept, which is supported by globalization: the innovation occurred in the developed world and multinationals export lightly modified versions of global products, with less functionalities. As a consequence, what was successful in the rich world it is supposed that will have acceptance in the emerging one.

But, Govindarajan (2012) says that RI implies just the opposite: to develop products in emerging countries to meet needs and price points of local demographics and export them to developed realities, to new customers' segments. In other words, ideas are developed in emerging markets and then they are coaxed to flow uphill in developed markets. 
INDEPENDENT JOURNAL OF MANAGEMENT \& PRODUCTION (IJM\&P)

http://www.ijmp.jor.br

v. 9, n. 4, October - December 2018

ISSN: 2236-269X

DOI: 10.14807/ijmp.v9i4.816

Govindarajan and Trimble (2012) suggest that it is a counterintuitive phenomenon as it is easy to understand why a poor person would want a rich man's product, but -on the contrary- why a rich man would want a poor's man product.

Govindarajan (2012) insists that this matter possess a huge challenge as firms must outstrip their dominant logic revamping old organizational structures, product development areas, production methods and, also, reorienting the sales force. That is the case of Harman, a company focused on electronic, audio and connectivity systems for vehicles.

In 2007, Paliwal became the Harman CEO and its infotainment division was poorly adapting premium products to lowered-priced segments (globalization). It had $70 \%$ share of the market and accounted two-thirds of the 3 billion revenues, but the high end products had little to grow. That is why Paliwal approached new opportunities in developing markets with the following main premises:

- Setting a team in China and another in India, with high goals, such us maintaining functionalities, and highly slashing costs and prices.

- Establishing a new engineering culture, new design methods and a novel organizational structure, which included friendly architecture; scalability; simplicity; modularity; third party and standard solutions; and a cheaper aftersale customization. As the approach used to perform the work was crossfunctional, unspecialized, experimental, adaptive and lean, technologies were segregated and subdivided having -in less than a year- a new architecture and scalable products that resemble the division's high-end systems in its functioning, meeting the cost/price aggressive targets.

- Setting change from bellow and above. Radical change was proposed from bellow with specific teams in emerging markets, and was supported from above by the CEO, orchestrating decisions and actions to make everything happen. This included establishing radical goals; practicing a clean-slate organizational design; leveraging global resources; choosing team leaders without conflicting interests; re-branding the product for emerging markets; shifting people, power and R\&D investments to emerging markets; improving knowledge and experience in emerging economies; managing business and assuring that actual products were not cannibalized. . 
INDEPENDENT JOURNAL OF MANAGEMENT \& PRODUCTION (IJM\&P)

http://www.ijmp.jor.br

v. 9, n. 4, October - December 2018

ISSN: 2236-269X

DOI: 10.14807/ijmp.v9i4.816

This new approach -shifting developments for emerging markets- had a lot of internal and external resistance, and was about to derail, but after Toyota accepted the new products every objection melted away.

Finally, they could offer a wide range of products, from low-end to luxury. First, they marketed these products to the development world and afterwards to the developed countries (carmakers that were looking for simplicity and low costs).

As of 2011 and in 18 months of the project, sales of this division amounted 3 billion dollars (a good part of the 5 year target of 5 billion dollars) and in the period 2009-2011 Harman's stock multiplied per 4 its value.

Harman went through two stages of their RI initiative. First, they marketed products in emerging markets and then in developed-countries manufacturers of lower prices. The third stage of this initiative is connected with a modular and scalable design and production for luxury markets.

Also, now they are looking at infotainment systems for motorbikes, an unexploited market for China, India and Southeast Asia. It will be based on a new platform, using the processing power of driver's cell phones at a target price of $\$ 20$.

As a result, Harman is pushing the limits of its capabilities through focusing on the urgency and needs of emerging markets, and balancing business as usual with radical thinking to provide better solutions to worldwide customers.

The study made by Govindarajan and Trimble (2012) remarks that the dynamic of innovation is changing and that, in certain circumstances, RI offers new and unexpected value, as it is shown in the following examples:

- Wal-Mart realized that in Central and South America shoppers lack the liquidity to buy in bulk and to maintain a home inventory. So, in order to enter into these markets they discovered that the "big box" they used should be radically scaled down to a "smaller box", selling less quantity and assortment of products.

In an after step, they realized that the small box was very useful in developed countries' cities in which space is small and rent is high. Dense urban realities are the rivalry of small competitors but with economies of scale in purchasing and supply chain management. 
INDEPENDENT JOURNAL OF MANAGEMENT \& PRODUCTION (IJM\&P)

http://www.ijmp.jor.br

v. 9 , n. 4, October - December 2018

ISSN: 2236-269X

DOI: 10.14807/ijmp.v9i4.816

- Narayana Health City (NH), Ahmedabad, is a hospital in India where an openheart surgery costs $\$ 2,000$ in comparison with US that costs $\$ 20,000$. Net profit margins are slightly higher in $\mathrm{NH}$ and mortality rates lower. This is the result of a change in an occidental basic assumption referred to the fact that every patient is unique and that a surgery is an opportunity for process innovation, comprising standardization, specialization of labor, economies of scale and assembly line production.

The fact is that through a fully utilization of resources and a slash in costs they perform hundreds of surgeries a day, as follows: a) it is used expensive equipment five times more if compared to US; b) doctors are more specialized in specific type of cardiac surgery; c) learning is accelerated; d) skills and quality of work are improved. As it is seen, cost is not a primary consideration but the last.

Moreover, in Cayman Island -one hour's flight from Miami, USA- NH opened a large 2,000-bed hospital at 50\% below US prices.

- Godrej \& Boyce Manufacturing, one of India's oldest industrial groups, has developed a $\$ 70$ fridge that runs on batteries, known as "the little cool". It is used by Indian farmers to have cold beverages while they are working, and in rich countries in other market segments like boating and camping.

As a result, the developing world responds to new needs and opportunities through firms that are big enough to change the rules of the game as Tata, Mahindra \& Mahindra, Reliance, Lenovo, Haier, Mindray and Suzlon, just to name some. As a result, the next generation of leaders must be curious about those fresh needs and opportunities.

The authors remark that RI proposes the following benefits:

- It is open to anyone and anywhere, needing ambition to go after it.

- It may redistribute power and wealth to countries and companies.

- It may accelerate the rise of poor countries and the decline of rich ones.

But it is not only about new companies that disrupt incumbents' markets. General Electric (GE) is a case that disrupted itself developing local technologies and -afterwards- distributing them globally. In the period 1980-2008, this process 
INDEPENDENT JOURNAL OF MANAGEMENT \& PRODUCTION (IJM\&P)

http://www.ijmp.jor.br

v. 9, n. 4, October - December 2018

ISSN: 2236-269X

DOI: 10.14807/ijmp.v9i4.816

made GE's revenues outside US soared from $19 \%$ of total revenues to more than half. The magic relied on understanding that $\mathrm{RI}$ requires a decentralized, localmarket focus which clashes with the centralized, product-oriented structure used by multinationals in globalization.

As an example and for India, GE developed a portable handheld electrocardiogram that is sold for around \$1,000 and for China, a low-cost and portable stethoscope, PC-based ultrasound, sold for as little as \$15,000 (a conventional ultrasound equipment may cost $+\$ 100,000)$. It is important to understand that -for China and India- portability is a must as patients hardly move to see a doctor if they are ill.

These kinds of products establish lower price points and even cannibalize higher-margin products in rich countries, defying also the original GE globalization model.

They conclude that:

- Emerging economies are growing at fantastic rates. That is the reason why RI projects-that flow uphill- must: a) be identified and pursue; b) global organizations must be aligned to emerging markets, creating new business units and scorecards; and c) strategy must come from a deeper comprehension of the differences between emerging and rich-market needs.

- It is required far more than simply geographic expansion to be successful in emerging countries. It is about understanding needs of emerging economies that are different from those at developed economies.

- Consumption should have its own understanding: in the rich world a few people spend a lot, but in the developing world many people spend little. The only way to approach this challenge is with $\mathrm{RI}$.

A summary of what it was said in this section can be seen in the following Tables: 


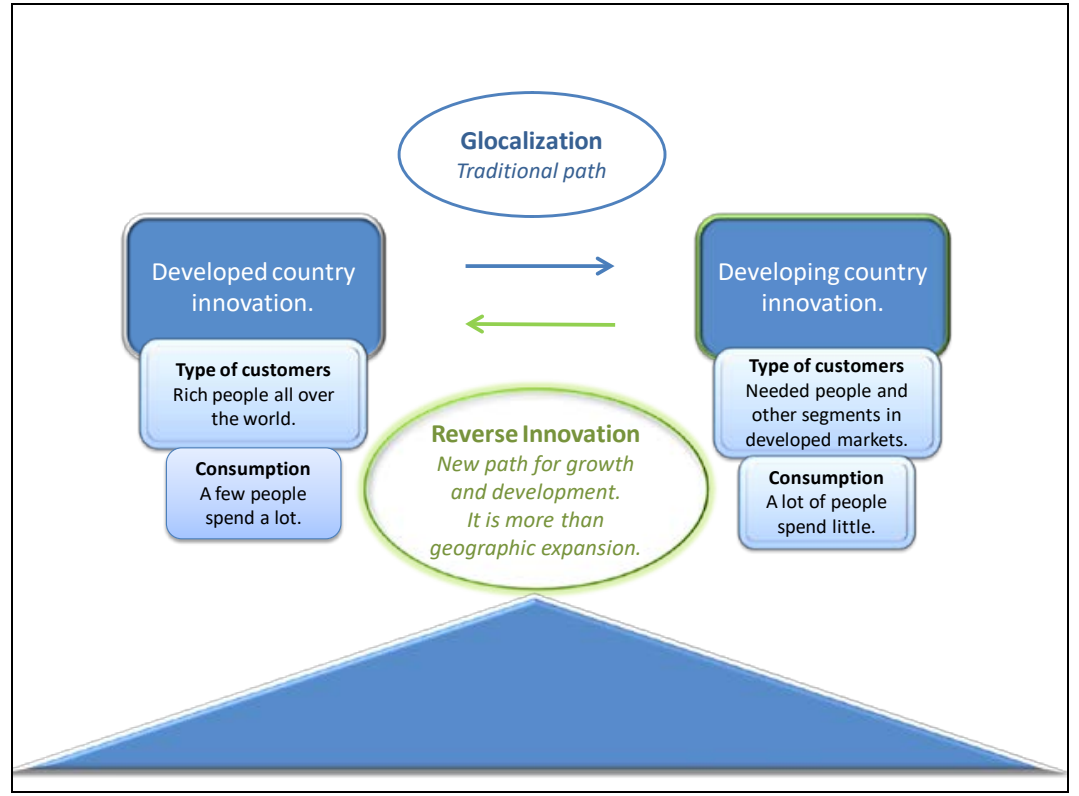

Figure 2: Reverse Innovation and Glocalization Source: Own

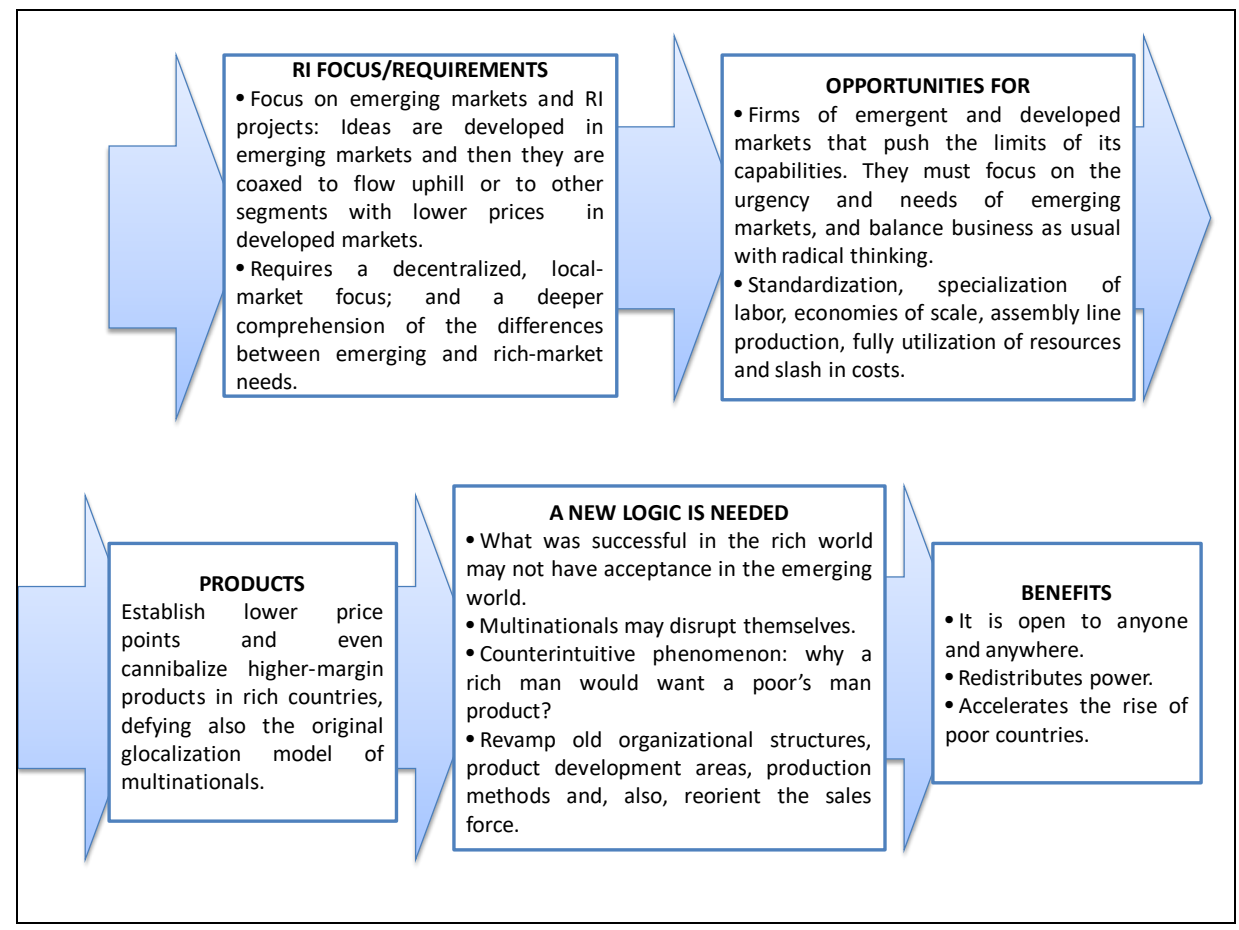

Figure 3: Reverse Innovation - Summary Source: Own

\section{DISRUPTIVE INNOVATION (DI)}

Christensen (2016) adverts that there are firms that are well run, with good competitive strategies, focused on their customers and that invest in new technologies but -anyway- they end up losing market domain. Companies like Sears (vast assortment of products at medium prices), Digital (that ignored PCs) and Xerox (that overlooked the growth of small desktop photocopiers) have a common 
INDEPENDENT JOURNAL OF MANAGEMENT \& PRODUCTION (IJM\&P)

http://www.ijmp.jor.br

v. 9, n. 4, October - December 2018

ISSN: 2236-269X

DOI: 10.14807/ijmp.v9i4.816

characteristic: the decisions that led to their subsequent collapse were taken when their leaders and companies were at the top of commercial and financial analysts' consideration.

Christensen, Anthony and Roth, (2004) suggest that: a) past formulas may not be applicable to the future; b) specific developments and customers may matter most; and c) contextual factors -like barriers to innovation put by non-market players- may influence innovation.

Christensen, (2016) shows that there are common factors in these kinds of organizations to be considered, like:

- Decisions are made in a way that sows the seed of eventual failure later.

- Principles of good management are not appropriate in certain circumstances.

- It's not always recommendable to listen to the best customers.

- It could be a good decision to invest in lower performing products with lower margins and to pursue small markets instead of more important ones.

As a result, he suggests to follow DI principles and technologies, and to understand that decisions -that seem logic in a specific context- may lead to lose market position or demise.

As it is remarked, DI principles may be summarized as follows:

- The pace of technological progress can be ahead of market needs as firms may innovate faster than their customers' needs, producing sophisticated or too-complicated products/services. The bases of these "sustaining innovations" success are that they: a) apply to the higher tiers of the market, supplying their most demanding and sophisticated customers, who bring greatest profitability and b) improve the performance of existing products/services in existing markets, being -generally- incremental. For this reason, these innovations rarely precipitate the failure of leading firms.

- Going upward, firms allow "disruptive innovators" to attack a new population of consumers at the bottom of the market (BoP markets, too) with products/services that historically were accessible to consumers who had a lot 
of money and/or a lot of skills. A disruptive product/service -at least at the initial stage- proposes:

o Simpler products/services: less functionalities and not-so-good performance, also below the actual minimum market requirements. These products/services are generally supplied by new firms, not by incumbents, as they propose lower gross margins and inferior prices.

o Smaller target markets.

o Much more consumers' accessibility.

o Less gross profit per product.

- These products/services are a more attractive solution when compared against traditional performance metrics. In addition and as they offer lower gross margins, are not attractive to firms moving upward in the market, creating an open space at the bottom of that market where the new disruptors emerge.

- This kind of technology precipitates the failure of leading firms as they bring a different value proposition to the market. Some examples are: Blockbuster, whose failure came from Netflix; Kodak, whose flop came first from the digital camera and then from the smartphone; the $\mathrm{PC}$, that precipitated the failure of big mainframes; discount sales, as an alternative to traditional retail purchases; and the Honda small motorcycles, creating the off-road market in USA.

- Failure of incumbent firms is possible as these products/services create a new value universe, understood as the context in which decisions are taken. In this environment, new parameters are considered in order to identify and respond to customers' needs; resolve problems; get comments; react to competitors; and struggle to make a profit. So, this context affects the economic value perceptions of a new technology and determines what is intended to be obtained by innovations (abrupt or sustained).

In other words, this new value universe displays a different attributes' classification of the product/service; has its own competitors; develops a different organizational structure and culture; assigns a different value to the 
same product/service attribute; and -finally- requires a specific cost structure. In addtion and speaking in terms of Michaels Porter's generic strategies, DI firms/products/services follow a cost leadership strategy?

- But, why incumbents flow uphill (in Govindarajan, Trimble's words) in their markets?, behavior that is influenced by the following three factors: 1) The promise of higher margins market up, 2) The simultaneous movement to higher markets of many of their customers, and 3) The difficulty of cutting costs to be able to move profitably down market.

- As it can be understood, sustainable innovations propose just opposite decisions in comparison with DI: Increase I\&D investments; longer planning and investment horizons; exploitation; forecast and technological planning; and research consortiums/joint ventures.

- In front of this situation, new entrants have advantages over the existing ones because their technologies do not generate value in the actual incumbent's value universe. It is not a technological issue, but it is about flexibility to modify strategies and cost structures.

- Customers and the financial structures of successful companies have an important influence -and, in general, in a negative way- on the type of investments that may be attractive when compared to firms that enter the lower-tier market. In an opposite manner, disruptive innovators are not tied to any customer.

Moreover, Christensen, Anthony and Roth (2004) advert that are seen signals of change and businesses opportunities when there are evaluated three customer groups:

o Undershoot customers, as firms are introducing up-market sustaining innovations and customers are frustrated with product's limitations.

o Non-consumers, showing that firms are introducing new-market disruptive innovations. These customers are not consuming any product or

${ }^{2}$ For more information see: Viltard, Leandro A. (2017) Strategic mistakes: The topicality of Michael's Porter generic strategies, Independent Journal of Management \& Production (IJM\&P), Abr-Jun, 2017, v8, n2. 
consuming in inconvenient settings as they lack the wealth, the access or the ability to accomplish a job for them.

o Overshot customers, as firms are introducing low-end disruptions, displacements or moving closer to customers and customers stop paying for further improvements in performance.

The authors suggest that circumstances may favor certain types of innovation. For instance, if circumstances favor up-market sustaining innovations firms should offer low-end disruptive products. Moreover, they say that lead customers must not be listened for disruptive innovations as these innovations are directed to a new market or to a low existing market.

In another work, Paris and Viltard (2017) highlight that there are firms in the emerging world that are not understanding $\mathrm{DI}$ and RI principles, and -despite having these kinds of products- they only use them with other objectives in mind, not as a contribution to the economic development and society welfare. This is the case of YPF (the Argentinean petroleum firm) that has implemented small and simpler service stations with aerial tanks (MAS, Modules of Social Supply, Módulos de Abastecimiento Social in Spanish).

They were used in the light automotive market and in small localities of the interior of Argentina, although they count with the potential to generate benefits for the community, the environment and YPF (SVC, Shared Value Creation concept developed by Porter and Kramer (2011) they were utilized only as corporate image in 15 distant towns with less of 2,000 people and service stations at +30 kilometers. Specifically, the MAS is a modular system with three modules: service, supply and beach loading.

They operate with alternative energy (wind turbines or solar panels) that provide much of the electrical energy necessary for their operation. In the following photo, it is shown a MAS: 
INDEPENDENT JOURNAL OF MANAGEMENT \& PRODUCTION (IJM\&P)

http://www.ijmp.jor.br

v. 9, n. 4, October - December 2018

ISSN: 2236-269X

DOI: 10.14807/ijmp.v9i4.816

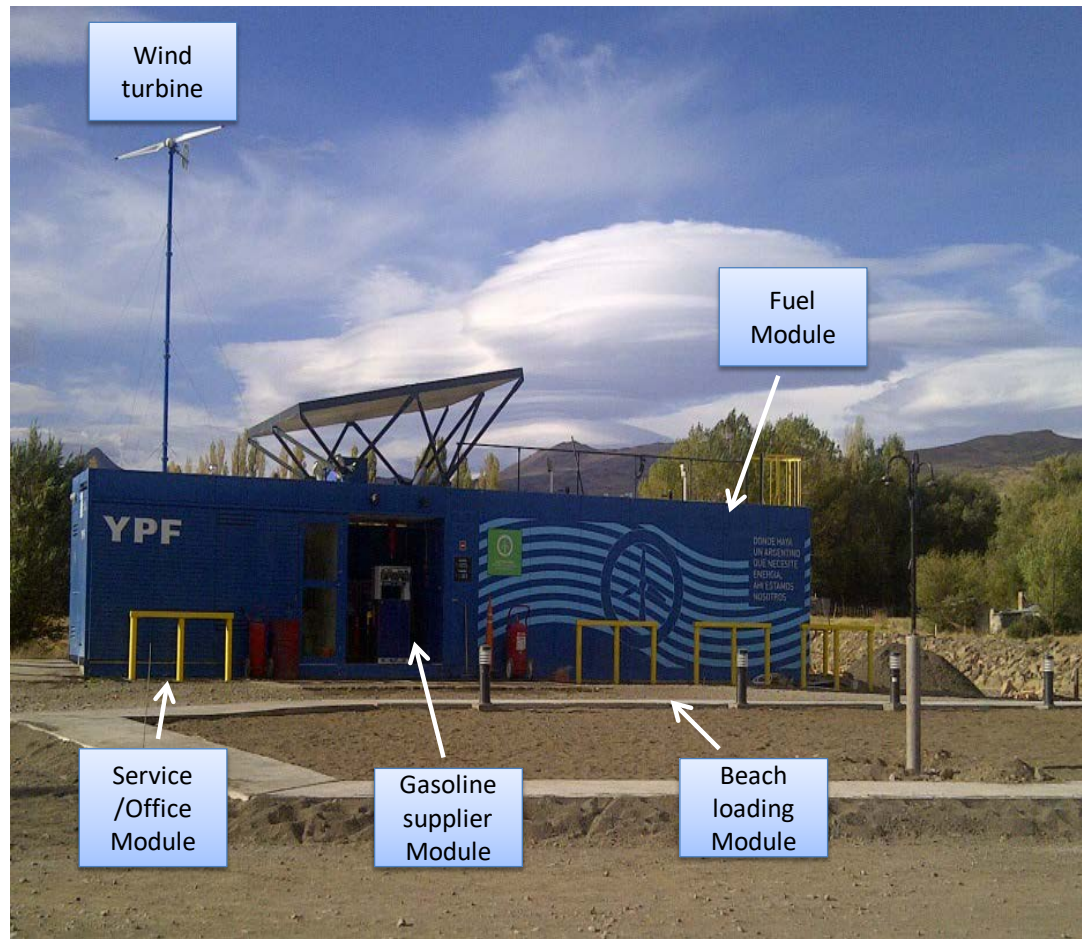

Photo 1: MAS located in El Huecú, Neuquén, Argentina Source: Own

Before the MAS installation, there were many people who make their living transporting fuel in drums and then storing it and selling it at $60 / 70 \%$ above its price. The way in which the fuel was transported and stored represented a latent danger for the population and the environment.

As a result of this study, It is stated that -as SVC reaches greater diffusion, scale and is combined with other strong innovation theories, in this case DI and RIcan become the support of a profitable and transformative business for companies, helping to solve or mitigate the environmental and social crisis that the planet is suffering. In addition, the MAS and similar products can be implemented in small towns and big cities -where space is scarse and expensive-, challenging the business of traditional gas stations.

As a conclusion on DI products/services, (CHRISTENSEN, 2016) says that they are a huge headache for managers, proposing not rational decisions, as they are:

- Simpler, cheaper and promise lower margins per product.

- At the beginning, they are sold in small markets and are adopted by less profitable customers. 
- Companies depend on their customers and investors to obtain their resources. That is the reason why the most profitable customers of the leading companies do not want and/or cannot use products/services based on disruptive technologies. As a consequence and if leaders want to be successful launching DI products/services, new market segments must be approached, with new rules and procedures.

Summarizing, DI products/services must:

- Find new markets that value their benefits, matching DI to the right customers.

- Be focused on small and profitable markets, anticipating failure in early stages and at reduced cost.

- Be developed in separate business units of the incumbent firms, with different policies, procedures and processes.

- Be understood as trial and error exercises as these markets didn't exist before and are difficult to be analyzed (in these cases every number is wrong). In this context, (VILTARD, 2015) insists that learning plans -and not business plans- are applicable

Finally and when DI makes base in a market, the author suggests that defenders/incumbents have three difficult decisions to take: 1) To leave the activity that they already know, 2) To continue with what they already have and work hard to improve or win customers, and/or 3) To continue their activity and start investing in the new technology to be prepared for the future.

A summary of this section is shown in the following Tables: 


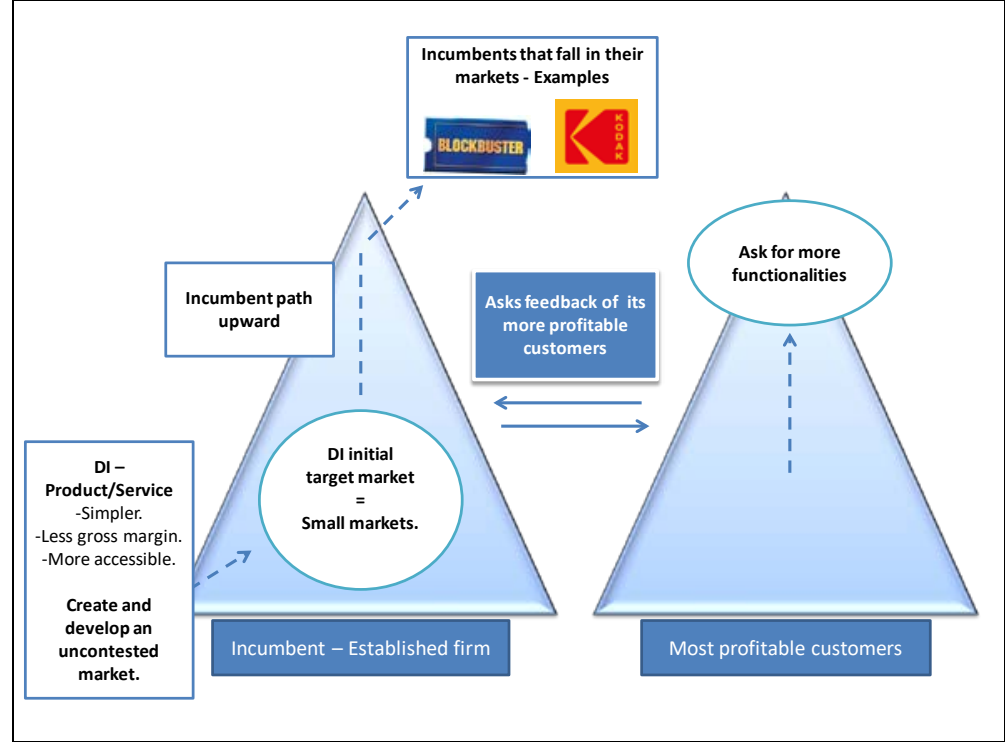

Figure 4: Disruptive Innovation (DI) path Source: Own

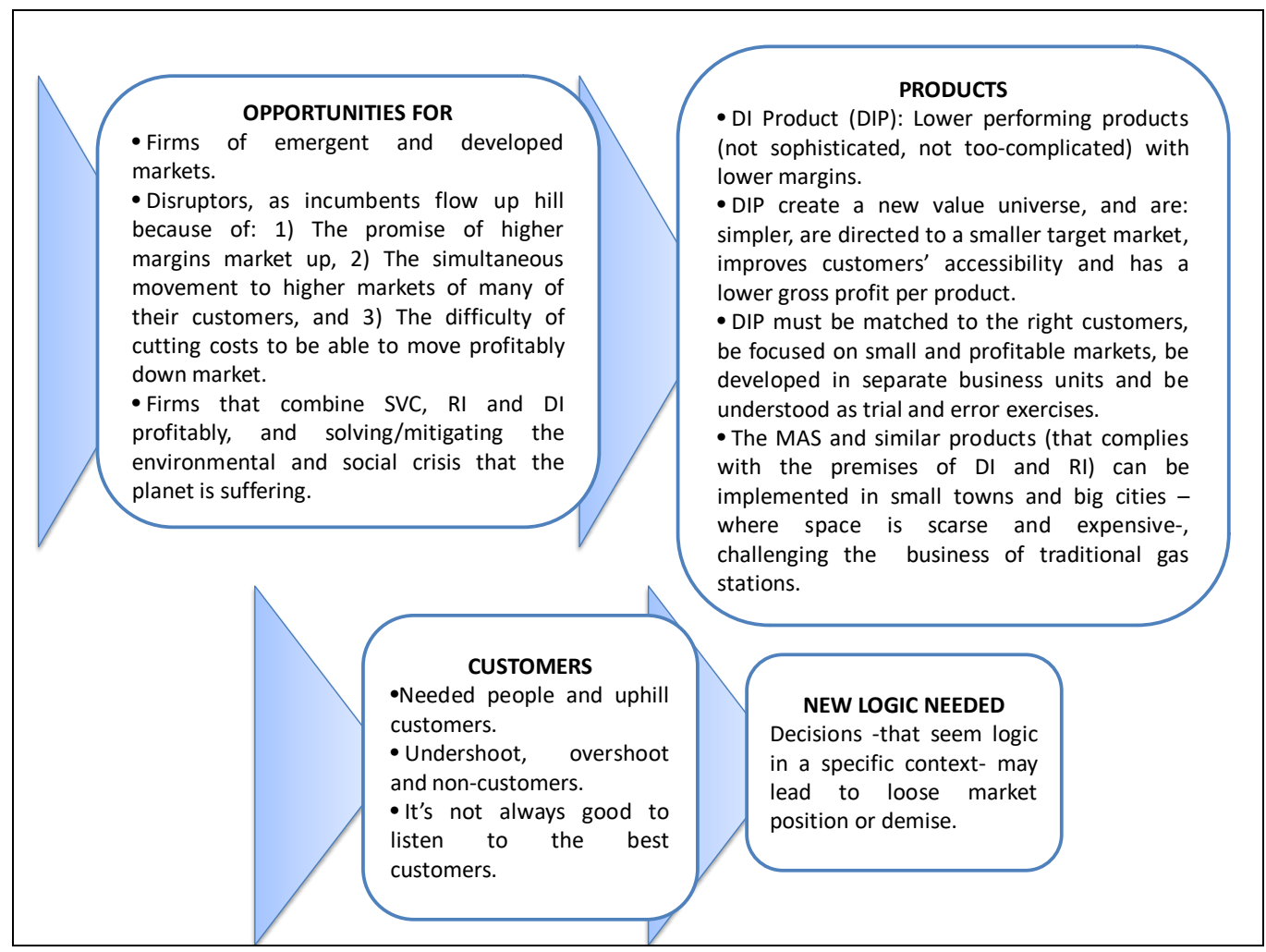

Figure 5: Disruptive Innovation (DI) Summary Source: Own

\section{THEORIES' COMPLEMENTATION}

As a result of the analysis performed in this study, these three theories -if adequately combined, understood and implement- may help to alleviate/eradicate poverty as they offer a common posture and reply to the same market segment, the BoP, as follows: 
a) Main objective pursued: they can help to eradicate/alleviate poverty, creating non contestable markets, and a new path for growth and development.

b) Focus: on emerging markets development, no matter if they are small at the beginning. Also, these markets are not limited to emerging economies, being an opportunity for the developed-world firms, too.

The BoP, DI and RI should be considered as basic elements of private firms' central mission. It is required a decentralized and local market focus, and a deeper understanding of the differences between emerging and rich-market needs.

c) Opportunity: for agile and optimist firms of emergent and developed markets that may work up a radical thinking and push the limits of its own capabilities to offer ultra-low prices/costs and serve new consumers' needs.

In these markets are applicable the following concepts: standardization, specialization of labor, economies of scale, assembly line production, fully utilization of resources and costs reduction to unimaginable limits.

SVC-Bop-RI-DI may become the basis to support a profitable and transformative business, helping to solve/mitigate the environmental and social crisis we are going through.

d) Products needed: they create a new value universe, establishing lower price points through an inferior performance and gross profit per product; frugality/simplicity (not sophisticated, not too-complicated); pre-paid; cheaper; collaborative consumption; healthy; unfancy brands; and reasonable places to shop. They can even cannibalize higher-margin products in rich economies (like what is proposed for the MAS project for traditional gas stations), disrupting, also, the glocalization model of multinational firms.

It is important to match them to the right customers, in small and profitable markets, and be developed in separate business units with trial and error exercises.

e) Targeted consumers: they are people who have unresolved needs, uphill customers and new segments in developed markets. They could be overshoot, undershoot and/or non-customers, but must be treated as 
consumers with a sense of value. It is not always recommendable to listen to the best customers of the upper-markets to serve this segment appropriately.

f) New logic needed: it is necessary to apply: a) creativity and innovation; b) understand that there are decisions that seem logic in a specific context that may not be applicable to these markets, and that what is successful in the rich world may not have acceptance in the emerging world; c) be respectful of these consumers and take into account the amount and variability of their cash flows; d) propose a drastic cost structure change; e) have a commitment to products' functionalities, not their form; f) focus on novel and advanced technologies, if needed; and g) assign the best executives to these markets.

Every firm should have a change in the actual dominant logic that governs its decisions, including multinationals that may disrupt themselves, as GE did.

It is required to revamp old organizational structures; product development areas and production methods; and reorient the sales force.

g) Benefits: as this approach is open to anyone and everywhere, it may redistribute power and accelerate the rise of poor countries. It proposes growth and development for firms and society; widen the economic benefits of the democracy of commerce; and improve social equality and balance for a sustainable and more livable world.

The following Tables show a summary of what was said in this section:

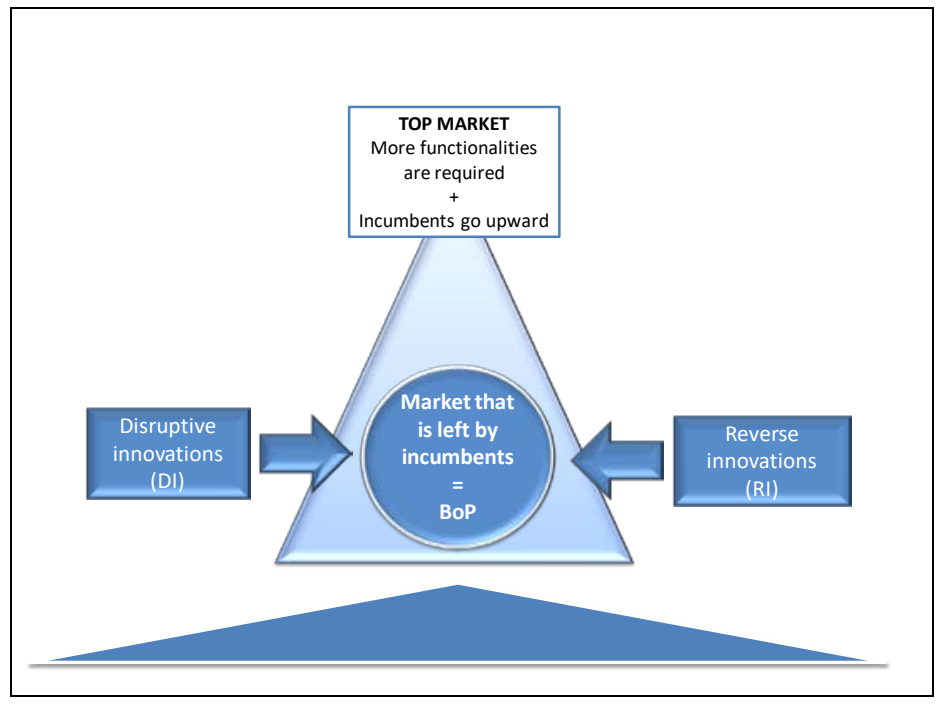

Table 6: Three theories combined - Focus

Source: Own 


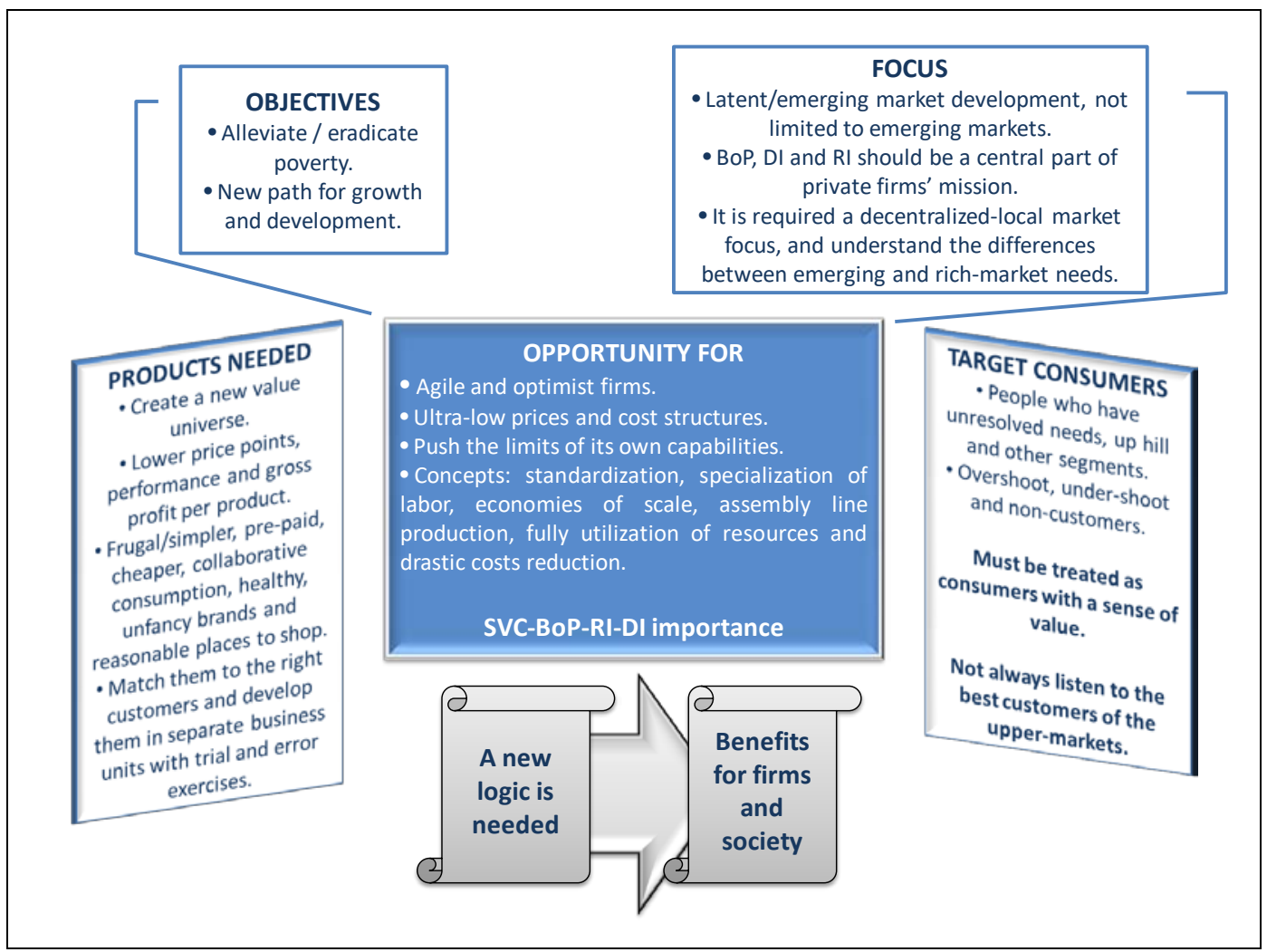

Figure 7: Three theories combined - Summary

Source: Own

\section{CONCLUSIONS}

For governments and organizations poverty is much more than a strategic, marketing or philanthropy issue; it is one of the scourges that whip our society.

It is suggested that -if it is developed a deeper comprehension on the three theories exposed in this study- it would be possible to change the actual dominant logic, give a reply to The Growth Imperative (TGI) and, finally, help to alleviate/eradicate poverty, giving dignity and better choices to the people who live at the BoP all over the world.

It is said that private organizations, local governments and other civil agencies may help on this crucial matter, but it is required a stronger intervention, based on the following pillars:

- Recognize the unbalance situation between the rich and the poor (BoP) as incrementally less people in the world can have a good quality of life and can be part of the production/consumer market. To be aware that this market is a 
crucial component of every country, no matter if it refers to a developed or emergent economy is vital to tackle this moon shot.

- Include the BoP into the economic value chain and make it part of a newlook and booming global economy, through:

o BoP principles comprehension that should: a) take into account the cash flow variability of these consumers; b) reinvent cost/price structures; c) be more committed to product's functionality, and to frugal, pre-paid and collaborative products; d) consider that technology does not necessarily means huge investments or state-of-the-art advances and e) assign the best talent to the BoP projects.

o Reverse Innovation (RI): has the capability to: a) redistribute wealth and power among countries and companies, b) may accelerate the rise of poor countries and c) it is open to everyone everywhere.

o Disruptive Innovation (DI), that proposes to focus on smaller and profitable markets, and to new customers' segments, for which simpler products and lower cost/price points are needed.

- Innovation implementation needs: a) More diffusion and better understanding of new theories that may help to tackle poverty in novel ways, b) Agile, disruptive and global organizations with aligned strategies to emerging markets, b) A separate business unit, with different policies, procedures and processes, c) Learning Plans (LP) -not Business Plans (BP)in which a fresh innovation culture and trial/error exercises should be part of the experience collected in these markets, understanding that failure is an opportunity to learn and go forward.

Summarizing, this study focus on poverty alleviation/eradication through giving dignity and better choices to the poor. This objective -a real moon shot (HAMEL, G, BREEN, B, 2013) 3.- may be achieved through The Growth Imperative Pillars, as it is shown in the following Table:

3 This concept is used by Hamel, G. and Breen, B. (2013) in The future of management, Harvard Business School Press, Boston, USA. It refers to a so high objective that seems as far as the 


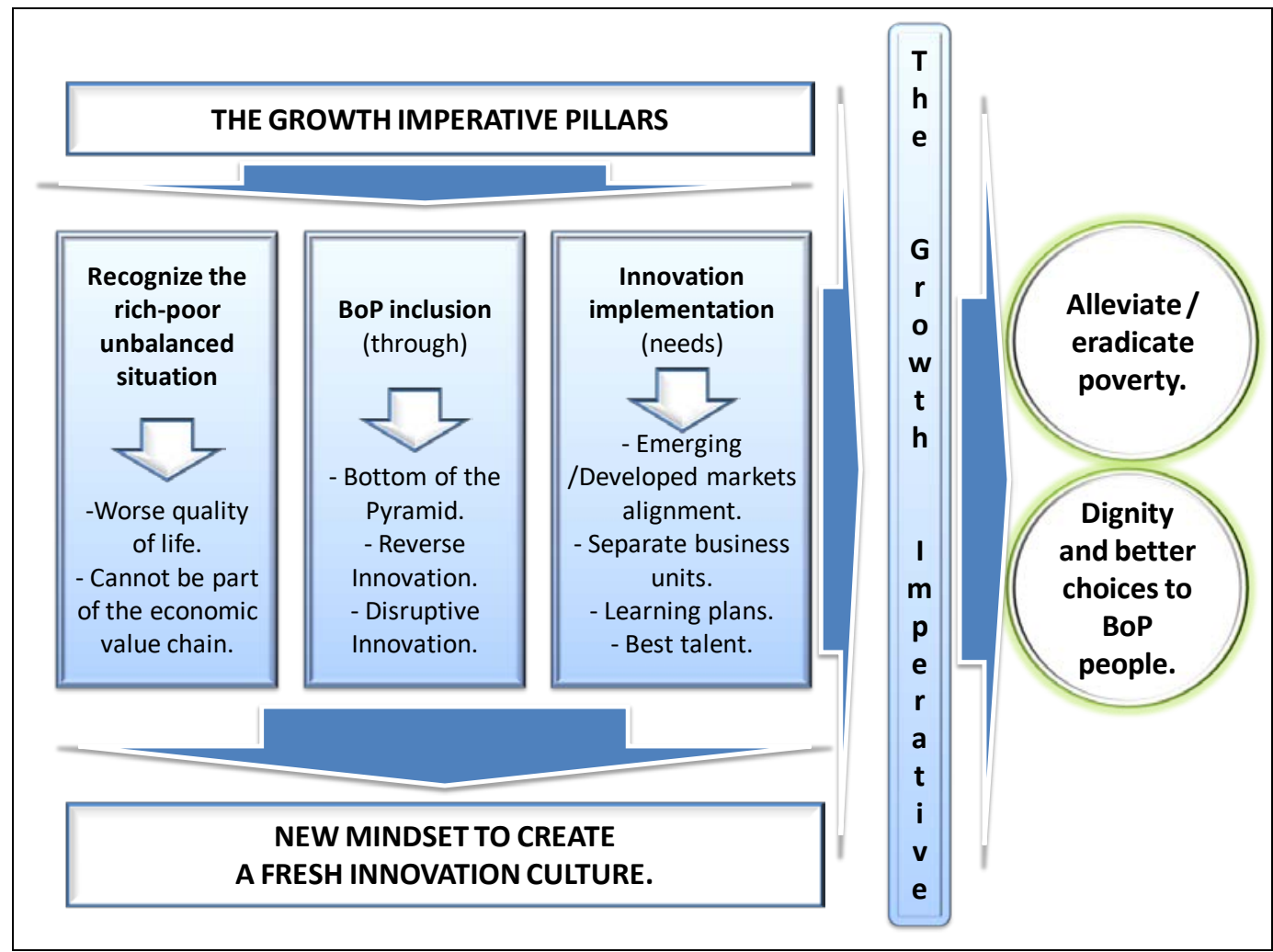

Figure 8: The Growth Imperative (TGI) Pillars

Source: Own

Global markets have become tough and volatile, and growth and development show to be an imperative for countries and organizations. In this context, emerging economies are growing at faster rates than developed economies but unequally, and geographic expansion is not enough to be successful in business.

Throughout this investigation it is indicated that a new logic must emerge in order to lay the foundations for the upcoming world. This should contain a deeper understanding of emerging economies customers' needs and on consumption differences between the developed and the developing worlds.

Novel theories show a different perspective on things that appeared to be stabilized by a dominant logic which -through decades- seemed immovable. New insights on management, entrepreneurship and each individual's value added should help with newer-found propositions which may come up with a fresh stage on the worldwide quality of life.

moon, but it is necessary to be taken into account in order to solve a so pressing scourge as the one we are studying: poverty in an impressive quantity of the worldwide population. 
INDEPENDENT JOURNAL OF MANAGEMENT \& PRODUCTION (IJM\&P)

http://www.ijmp.jor.br

v. 9, n. 4, October - December 2018

ISSN: 2236-269X

DOI: 10.14807/ijmp.v9i4.816

\section{REFERENCES}

CHRISTENSEN, C. (2016) The Innovator's dilemma, when new technologies cause great firms to fail, Harvard Business Review Press, Boston: USA.

CHISTENSEN, C.; ANTHONY, S.; ROTH, E. (2004) Seeing what's next, using the theories of innovation to predict industry change, Harvard Business School Press, Boston, USA.

CHRISTENSEN, C. M.; RAYNOR, M. E. (2003) The Innovator's Solution, creating and sustaining successful growth, Harvard Business School Press, Boston: USA.

GOVINDARAJAN, V.; TRIMBLE, C. (2012) Reverse innovation, create far from home, win everywhere, Harvard Business Review Press, Boston: USA.

GOVINDARAJAN, V. (2012) A reverse-innovation playbook, retrieved from https://hbr.org/2012/04/a-reverse-innovation-playbook, on 04/26/2018.

HAMEL, G.; BREEN, B. (2013) The future of management, Harvard Business School Press, Boston, USA.

PARIS, J. M.; VILTARD, L. A. (2017) Innovación y Creación de Valor Compartido (Innovation and Shared Value Creation), Palermo Business Review, n. 15.

PORTER, M. E.; KRAMER, M. R. (2011, enero). La creación de valor compartido (Shared Value Creation), Harvard Business Review, América Latina, Boston: USA.

PRAHALAD, C. K. (2004) The fortune at the bottom of the pyramid, eradicating poverty through profits, Wharton School Publishing, NJ: USA.

THE ECONOMIST (Jun., 23 ${ }^{\text {rd }}, 2011$ ) The bottom of the pyramid, Businesses are learning to serve the hard up Americans, retrieved from https://www.economist.com/node/18863898, on 04/27/2018.

VILTARD, L. A. (2017) Strategic mistakes: The topicality of Michael's Porter generic strategies, Independent Journal of Management \& Production, v. 8, n. 2.

VILTARD, L. A. (2015) The death of the Business Plan: More than ever learning plans and not business plans are meant to analyze most of business growth alternatives, Independent Journal of Management \& Production, v. 6, n. 4. 